\title{
Biodegradation of carbaryl and phthalate isomers by soil microorganisms
}

\author{
P. S. Phale \\ Biotechnology, School of Biosciences and Bioengineering, \\ Indian Institute of Technology-Bombay, Powai, Mumbai-400 076, India
}

\begin{abstract}
Pseudomonas sp. strain PP4 and C5 utilize phthalate isomers (o-, $m$ - and $p$-) and carbaryl as carbon source, respectively. Degradative pathways were elucidated by isolating and characterizing metabolites, whole-cell $\mathrm{O}_{2}$ uptake and enzyme activity studies. Metabolic studies suggest that phthalate isomer degrading pathways converge at 3,4-dihydroxybenzoic acid. Phthalate dioxygenases responsible for the degradation of the respective phthalate isomers are induced specifically, suggesting that probably there are three different phthalate dioxygenases. This was supported by whole-cell $\mathrm{O}_{2}$ uptake studies and cells grown on glucose failed to show the activity of phthalate pathway enzymes. Glucose-grown cells lost the phthalate degradation property indicating probable involvement of plasmid, which is expressed and maintained selectively in the presence of phthalate isomers. The metabolic studies with Pseudomonas sp. strain C5 suggest that carbaryl is first hydrolyzed to 1-naphthol by carbaryl hydrolase. Generated 1-naphthol is metabolized via 1,2-dihydroxynaphahtlane, salicylate and gentisic acid to TCA cycle intermediates, thus serving as the sole source of carbon and energy. The ability to utilize phthalates $(0.3 \%)$ and carbaryl (1\%) at high concentrations make these strains suitable candidates for bioremediation. Detailed understanding of metabolic pathways and genetic make-up will enable one to modify these strains by genetic engineering tools for suitable application in bioremediation.
\end{abstract}

Keywords: Phthalate degradation, Carbaryl metabolism, oxygenases, bioremediation, pseudomonas. 


\section{Introduction}

Aromatic hydrocarbons are used heavily in various industries, which found their way in to soil, water and air thus polluting the environment. Due to the persistence of these toxic and carcinogenic compounds in nature, microbes have evolved with novel metabolic pathways to release the 'Locked Carbon'. Phthalate isomers ( $o$-, $m$ - and $p$-) and their esters are major industrial pollutants, used heavily in plastic, textile, paint, pesticide carrier, munition, and cosmetic industries. The majority of them are recalcitrant and toxic causing teratogenic, reproductive and neuromuscular disorders [1]. The microbial metabolism of $o$ phthalate is well studied. Many Pseudomonas sp. have been reported to degrade $o$-phthalate and phthalate esters to 4,5-dihydroxyphthalate, which enters into the TCA cycle via 3,4-dihydroxybenzoate [2]. However very little is known about the degradation of tere- and iso-phthalate. So far there are no reports on a single bacterial strain degrading all three phthalate isomers as the sole carbon source. Besides an environmental pollutant, isophthalate is known to be a competitive inhibitor of glutamate dehydrogenase (GDH) responsible for conversion of $\alpha$ ketoglutarate to glutamate [3].

Carbamate insecticides, such as carbaryl (1-naphthyl- $N$-methylcarbamate), are highly toxic with a wide range of activities and are used heavily in agricultural industry. Carbamates are competitive inhibitors of neuronal nicotinic acetylcholine receptors and acetylcholinesterase [4]. $\mathrm{N}$-Nitrosocarbamates and 1naphthol generated are potent mutagens, more toxic and recalcitrant than carbaryl itself $[5,6]$. Microbial metabolic studies have indicated that the first step in degradation is hydrolysis of carbaryl to 1-naphthol by hydrolase. Depending on the strain, 1-naphthol is metabolized via salicylate to either gentisate or catechol [7-10], however the steps and enzymes responsible for the conversion of 1-naphthol to salicylate have not been demonstrated so far.

We have isolated two soil bacterial strains capable of utilizing phthalate isomers and carbaryl. Here we are presenting the metabolic pathway and inhibition of GDH by isophthalate in strain PP4. Based on the metabolic studies, we propose the carbaryl degradation via 1,2-dihydroxynaphthalene (1,2-DHN) in Pseudomonas sp. strain C5.

\section{Materials and methods}

\subsection{Organism and growth}

Pseudomonas sp. strain PP4 and C5 were isolated by an enrichment culture technique from soil contaminated with petroleum products. Strains were grown on Minimal Salt Medium [11] at $30^{\circ} \mathrm{C}$ with appropriate carbon source.

\subsection{Metabolite isolation, bio-transformation and whole-cell $\mathrm{O}_{2}$ uptake studies}

To isolate and identify carbaryl metabolites, a late-log phase spent medium was acidified to $\mathrm{pH} 2$ with $2 \mathrm{~N} \mathrm{HCl}$ and extracted with equal volume of ethyl acetate, 
dried over anhydrous sodium sulfate, concentrated and analyzed by TLC using Hexane:Chloroform:Acetic acid 8:2:1 (v/v/v). Metabolites were identified by TLC ( $\mathrm{R}_{\mathrm{f}}$ and UV-fluorescence), GC-MS and UV-Visible spectroscopy. GC-MS analysis was carried out on Hewlett-Packard G1800A mass spectrometer attached to a gas chromatograph as described [12]. Whole-cell $\mathrm{O}_{2}$ uptake rates were monitored as described [13], using an Oxygraph (Hansatech, UK) fitted with Clark's type $\mathrm{O}_{2}$ electrode. Rates were corrected for endogenous $\mathrm{O}_{2}$ consumption and expressed as nmol of $\mathrm{O}_{2}$ consumed $\min ^{-1}$ (mg wet cells) ${ }^{-1}$.

\subsection{Preparation of cell-free extracts, enzyme assays and activity staining}

PP4 cells were harvested, washed and suspended in buffer HEPES $(20 \mathrm{mM}, \mathrm{pH}$ $8.5)$, EDTA $(1 \mathrm{mM})$ and $\mathrm{NaCl}(100 \mathrm{mM})$ and disrupted by sonication using an Ultrasonic processor (model GE130, USA) at $4^{\circ} \mathrm{C}$. The cell homogenate was centrifuged and the supernatant was used as the source of enzyme. GDH was assayed spectrophotometrically and activity staining was performed as described [14]. Pseudomonas C5 cells were suspended in K-phosphate buffer (50 mM, pH $7.5, \mathrm{~K}_{-} \mathrm{PO}_{4}$ buffer) and disrupted by sonication at $4^{\circ} \mathrm{C}, 4$ cycles of 15 pulses each, out-put 11 watt. Cell homogenate was centrifuged at $40,000 \mathrm{~g}$ for $30 \mathrm{~min}$ at $4^{\circ} \mathrm{C}$. The clear membrane-free supernatant obtained was referred to as cell-free extract and used as enzyme source. Carbaryl hydrolase $(\mathrm{CH})$ was monitored spectrophotometrically by measuring the rate of increase in absorbance at 322 $\mathrm{nm}$ due to formation of 1 -naphthol. The reaction mixture $(1 \mathrm{ml})$ contained substrate $(100 \mu \mathrm{M})$, an appropriate amount of enzyme and $\mathrm{K}-\mathrm{PO}_{4}$ buffer. The activity was calculated by using molar extinction coefficient of 1-naphthol $\varepsilon_{322 \mathrm{~nm}}$ 2200 in $\mathrm{K}_{-}-\mathrm{PO}_{4}$ buffer. 1-Naphthol hydroxylase (1-NH) was monitored by the oxygraph method. The reaction mixture $(2 \mathrm{ml})$ contained $\mathrm{K}-\mathrm{PO}_{4}$ buffer, substrate $(100 \mu \mathrm{M})$, FAD $(6.25 \mu \mathrm{M})$ and NADH $(100 \mu \mathrm{M})$. Reaction was started by addition of an appropriate amount of enzyme. 1,2-Dihydroxynaphthalene dioxygenase (12DHNO, 15), gentisate dioxygenase (GDO, 16), protocatechuate dioxygenase $(\mathrm{PDO}, 17)$ and catechol dioxygenase $(\mathrm{CO}, 18)$ were monitored as described. The specific activities are reported as nmol. $\mathrm{min}^{-1} \cdot \mathrm{mg}^{-1}$ of protein. Protein estimation was carried out as described [19].

\section{Results and discussion}

\subsection{Metabolism of phthalate isomers by Pseudomonas strain PP4}

Pseudomonas strain PP4 has the ability to utilize all three-phthalate isomers as the sole source of carbon. Cell respiration studies are summarized in Table 1. Cells grown on isophthalate showed good respiration on isophthalate and 3,4DHB and similar results were observed for other phthalate isomers. The cells failed to respire on 2,3-DHB and 2,5-DHB (Table 1). These results suggest that specific phthalate isomer induces respective phthalate dioxygenase responsible for the initial ring hydroxylation, which is further metabolized to TCA cycle intermediate via 3,4-DHB. Glucose-grown cells failed to show $\mathrm{O}_{2}$ uptake 
suggesting that the enzymes are inducible. Based on these results the proposed pathway is as shown in Fig.1.

Table 1: Whole-cell $\mathrm{O}_{2}$ uptake rates by strain PP4 grown on different carbon sources (Iso, Isophthalate; Pht, Phtalate; Tere, Terephthalate; Glc, Glucose; DHB, dihydroxybenzoate; nd, not detected; tr, $\mathrm{O}_{2}$ uptake < $\left.0.5 \mathrm{nmol} \mathrm{min}^{-1} \mathrm{mg}^{-1}\right)$.

\begin{tabular}{rcccccc}
\hline & \multicolumn{6}{c}{ Cell respiration on intermediates, $\mathrm{nmol} \mathrm{O}_{2}$ consumed $\mathrm{min}^{-1} \mathrm{mg}^{-1}$} \\
\cline { 2 - 7 } Carbon & Iso & Pht & Tere & $3,4-\mathrm{DHB}$ & $2,3-\mathrm{DHB}$ & $2,5-\mathrm{DHB}$ \\
\hline Iso & 1.6 & nd & nd & 2.6 & $\operatorname{tr}$ & $\operatorname{tr}$ \\
Pht & nd & 3.5 & nd & 2.7 & $\operatorname{tr}$ & 1.2 \\
Tere & nd & nd & 3.5 & 1.9 & nd & $\operatorname{tr}$ \\
Glc & tr & tr & tr & tr & tr & tr \\
\hline
\end{tabular}

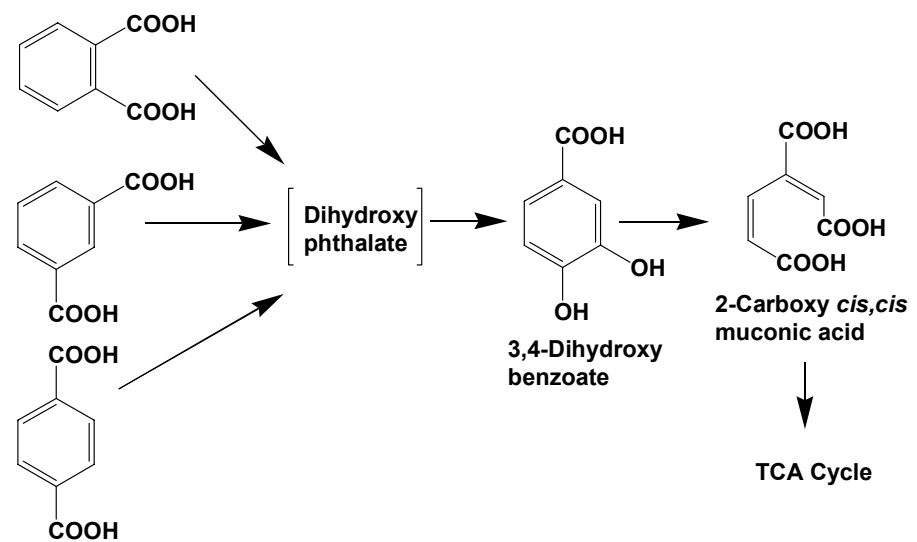

Figure 1: Proposed pathway for the degradation of three phthalate isomers by strain PP4.

The metabolic pathway for phthalate is studied in detail for various enzymes involved, gene regulation and role of plasmids. However, not much information is available on the degradation of iso- and tere-phthalates. Strain PP4 is unique and utilizes all phthalate isomers and converges metabolic pathway into 3,4DHB. Generated 3,4DHB is ring cleaved to 2-carboxy-cis,cis-muconic acid which enters TCA cycle, thus serving as the sole source of carbon and energy. When grown on simple carbon source like glucose, the cells lost their ability to degrade phthalate isomers, suggesting that probably the degradation phenotype is unstable in the absence of specific carbon source and probably genes are located on the plasmid. 


\subsection{Isophthalate as GDH inhibitor}

GDH catalyzes reversible reaction, and equilibrium favors glutamate synthesis. In microorganisms, the biosynthetic reaction of GDH (ammonia assimilating) is catalyzed by NADP-GDH while the oxidative deamination reaction is catalyzed by NAD-GDH. Strain PP4 has NADP-GDH when grown on isophthalate. Glutamate-grown cells had high NAD-GDH activity compared to glucose-grown cells (Table 2). Inhibition of GDH by isophthalate $(1 \mathrm{mM})$ is shown in Table 2. $\mathrm{GDH}$ from glucose grown PP4 is more sensitive (66\%) to isophthalate inhibition compared to $\mathrm{GDH}$ from isophthalate grown cells $(28 \%)$.

Table 2: Specific activity of GDH and its inhibition by isophthalate $(1 \mathrm{mM})$. (Glc, glucose; Glu, glutamate; nd, no activity detected; values in bracket are \% inhibition).

\begin{tabular}{rccc}
\hline & \multicolumn{3}{c}{ Amination reaction } \\
\cline { 2 - 4 } Growth on & NADH & NADPH & NADPH+Iso \\
\hline Iso & nd & 231 & $166(28)$ \\
Glc & 28 & 184 & $63(66)$ \\
Glu & 108 & 41 & $22(47)$ \\
\hline
\end{tabular}

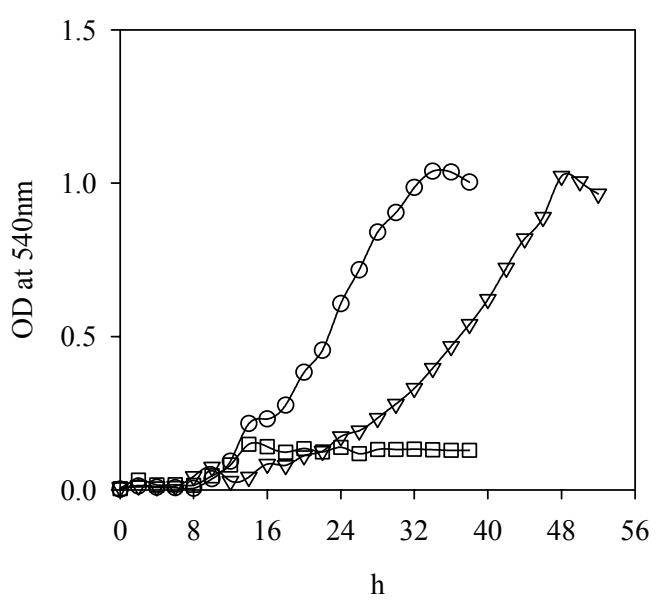

Figure 2: Effect of glutamate on the growth profile of strain PP4 on isophthalate $(\nabla)$; iosphthalate + glutamate $(\bigcirc)$ and glutamate $(\square)$.

Strain PP4 when grown on isophthalate showed a lag phase of $\sim 20 \mathrm{~h}$ and reached a stationary phase by $48 \mathrm{~h}$. When supplemented with $1 \mathrm{mM}$ glutamate, cells grew faster with short lag phase $(12 \mathrm{~h})$ and reached a stationary phase around $34 \mathrm{~h}$ (Fig. 2). In the initial phase of the growth, glutamate is taken up by the cells, which might be helping to overcome the inhibition by isophthalate and hence the culture is growing faster with small lag phase. NADP-GDH activity 
staining was done with crude extracts from PP4 grown on different carbon sources. The staining pattern for PP4 on isophthalate showed a staining band of lower mobility compared to glucose grown cells. These results suggest that in strain PP4 two GDH isozymes are present and induced depending on the carbon source.

Rapid growth on isophthalate in the presence of glutamate and carbon source dependent changes in the isozyme pattern suggests inhibition of GDH by isophthalate in vivo. Probably, isophthalate is acting as a metabolic inhibitor.

\subsection{Metabolism of Carbaryl by Pseudomonas sp. strain C5}

To elucidate the carbaryl degradative pathway, metabolites were extracted and resolved by TLC. Four major spots with $\mathrm{R}_{f}$, UV fluorescence and GCMS properties similar to authentic carbaryl, 1-naphthol, salicylate and gentisate were identified (Table 3). The analysis failed to detect spots corresponding to 1,4naphthoquinone and catechol. To elucidate the metabolic sequence, biotransformation experiments were performed using carbaryl, 1,4naphthoquinone and salicylaldehyde. When cells were supplemented with carbaryl, TLC showed metabolite spots similar to authentic carbaryl, 1-naphthol, salicylate and gentisate. With salicylaldehyde, two major metabolites salicylate and gentisate were detected. However no metabolites with 1,4-naphthoquinone were observed.

Table 3: $\quad$ Identification of carbaryl metabolites from the spent media.

\begin{tabular}{|c|c|c|c|c|}
\hline & TLC & \multirow{2}{*}{$\begin{array}{l}\text { UV-Vis } \\
(\mathrm{nm})\end{array}$} & \multirow{2}{*}{$\begin{array}{l}\text { MS analysis }\{\mathrm{m} / \mathrm{z}(\% \\
\text { relative } \\
{[\text { intensity })} \\
[\text { olecular ion }]\}\end{array}$} & \multirow[t]{2}{*}{ Inference } \\
\hline $\mathrm{R}_{f}$ & UV-Fluo & & & \\
\hline 0.62 & Dark blue & $\begin{array}{l}280, \quad 312, \\
318\end{array}$ & $\begin{array}{lr}201(4)\left[\mathrm{M}^{+}\right], & 144(100), \\
127(3), & 115(52), \\
89(10), 77(2) & \end{array}$ & Carbaryl \\
\hline 0.73 & Brown black & $\begin{array}{l}298, \quad 308, \\
323\end{array}$ & $\begin{array}{l}144(100)\left[\mathrm{M}^{+}\right], 115(77), \\
88(10), \\
77(2)\end{array}$ & 1-Naphthol \\
\hline 0.77 & Sky blue & 306 & -- & Salicylate \\
\hline 0.15 & Blue-green & 338 & $\begin{array}{l}\text { 154(37) }\left[\mathrm{M}^{+}\right], 136(100), \\
108(10), 77(1)\end{array}$ & Gentisate \\
\hline
\end{tabular}

To elucidate steps involved in the conversion of 1-naphthol to salicylaldehyde, whole-cell $\mathrm{O}_{2}$ uptake rates, enzyme activities in the cell-free extracts and products of bulk enzyme reactions were monitored. Cells showed good $\mathrm{O}_{2}$ uptake on carbaryl, 1-naphthol, 1,2-DHN, salicylate and gentisate (Table 4). Salicylate grown cells showed $\mathrm{O}_{2}$ uptake on salicylate and gentisate but significantly low respiration on carbaryl, 1-naphthol, 1,2-DHN and salicylaldehyde. However, glucose grown cells showed very low respiration (Table 4). 
Table 4: Whole-cell $\mathrm{O}_{2}$ uptake rates for cells grown on various carbon sources.

\begin{tabular}{rccc}
\hline & \multicolumn{3}{c}{$\mathrm{O}_{2}$ uptake* $^{*}$ (nmol of $\mathrm{O}_{2}$ consumed } \\
& $\mathrm{min}^{-1} \cdot \mathrm{mg}^{-1}$ & cells), cells grown on \\
\cline { 2 - 4 } & Carbaryl & Salicylate & Glucose \\
\hline Carbaryl & 3.8 & $\operatorname{tr}$ & $\operatorname{tr}$ \\
1-Naphthol & 7.8 & $\operatorname{tr}$ & $\operatorname{tr}$ \\
1,2-DHN & 1.0 & $\operatorname{tr}$ & $\operatorname{tr}$ \\
1,4-Naphthoquinone & $\operatorname{tr}^{\#}$ & $\operatorname{tr}$ & $\operatorname{tr}$ \\
Salicylaldehyde & 4.4 & 0.4 & $\operatorname{tr}$ \\
Salicylate & 1.2 & 0.7 & $\operatorname{tr}$ \\
Gentisic acid & 1.7 & 1.0 & $\operatorname{tr}$ \\
Catechol & tr & $\operatorname{tr}$ & $\operatorname{tr}$ \\
* Values corrected for endogenous $\mathrm{O}_{2}$ uptake; \# tr, uptake rates $<0.3 \mathrm{nmol}$.
\end{tabular}

Table 5: $\quad$ Various enzyme activities from the cell-free.

\begin{tabular}{|c|c|c|c|}
\hline \multirow[t]{2}{*}{ Enzyme } & \multicolumn{3}{|c|}{ Specific activity, nmol. $\mathrm{min}^{-1} \cdot \mathrm{mg}^{-1}$ protein } \\
\hline & Carbaryl & Salicylate & Glucose \\
\hline $\mathrm{CH}$ & 71 & 1.1 & 1.1 \\
\hline $1-\mathrm{NH}$ & 270 & 4 & 2 \\
\hline 1,2-DHNO & 52 & 32 & 29 \\
\hline GDO & 425 & 601 & 1 \\
\hline $\mathrm{CO}$ & 56 & 55 & 39 \\
\hline
\end{tabular}

Specific activities of $\mathrm{CH}, 1-\mathrm{NH}, 1,2-\mathrm{DHNO}$ and GDO are summarized in Table 5. Salicylate cultures showed a comparable activity of GDO and a significantly low activity of $\mathrm{CH}$ and 1-NH. All enzyme activities from glucose grown cells were significantly low (Table 5). The enzyme activities and wholecell $\mathrm{O}_{2}$ uptake rates from carbaryl and glucose grown cells suggest that the enzymes are inducible. Involvement of 1-naphthol and salicylate in carbaryl metabolism is reported earlier. Here we demonstrate, for the first time, the presence of 1-NH and 1,2-DHNO activities in the cell-free extract of carbaryl degrading strains. 1-NH was studied for its cofactor and $\mathrm{O}_{2}$ requirement. Under aerobic conditions the cell-free extract showed conversion of 1-naphthol to salicylate in the presence of $\mathrm{NADH}$ and FAD. However under anaerobic conditions, we failed to detect salicylate. These results suggest that the enzyme is oxygenase type and requires $\mathrm{O}_{2}$ for its optimum activity. The enzyme showed good activity with FAD and NADH. When NADPH and FAD were used as cofactors, $20-30 \%$ increase in activity was observed.

Based on metabolite studies, we propose a degradative pathway for carbaryl in strain C5 as shown in Fig. 3. 


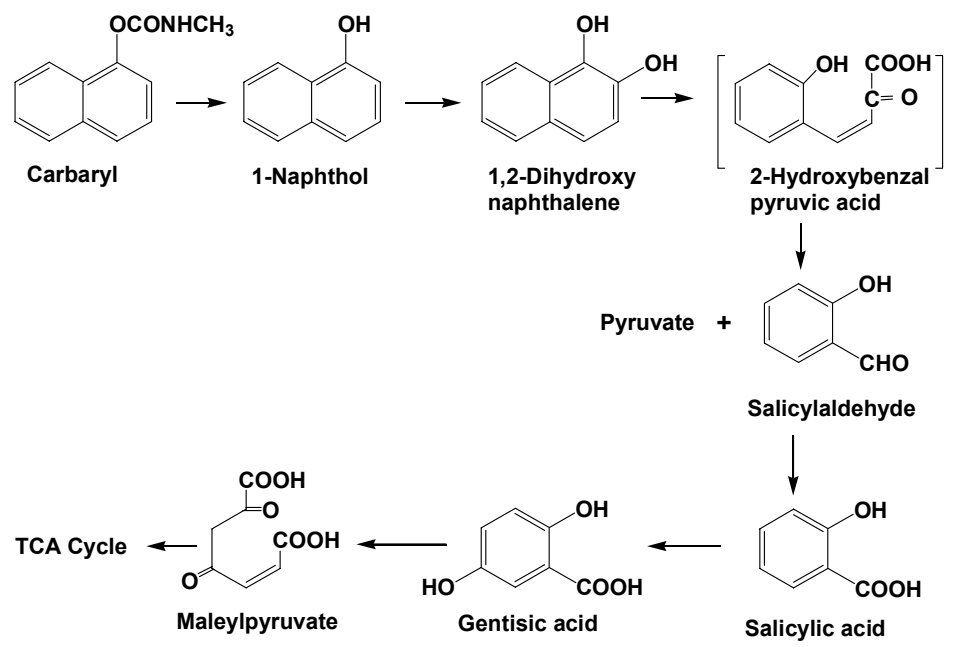

Figure 3: Proposed pathway for the degradation of carbaryl in Pseudomonas sp. strain C5.

It has been proposed that prior to ring cleavage, 1-naphthol is hydroxylated either to 4-hydroxy-1-tetralone [21], 3,4-dihydro-dihydroxy-1(2H)naphthalenone [22] or 1,4-naphthoquinone [23]. Detection of 1-NH, and 1,2DHNO activity and whole cell $\mathrm{O}_{2}$ uptake on 1-naphthol and 1,2-DHN strongly suggests $1,2-\mathrm{DHN}$ as intermediate in the pathway. The pathway from 1,2-DHN onward is similar to the naphthalene metabolic pathway, however strain C5 failed to utilize naphthalene.

In conclusion, strains PP4 and C5 are unique, degrade phthalate isomers and carbaryl at higher concentrations, respectively. These strains are isolated from the environment and are very efficient in degradation of compounds of interest. Further characterization and genetic engineering of these strains helps in the degradation of a wide range of aromatic hydrocarbons efficiently. Development of such a metabolically engineered strain has an advantage and will help in effective bioremediation and environmental pollution clean up processes.

\section{Acknowledgement}

We thank DBT, Govt. of India for the Research grant.

\section{References}

[1] Lovecamp, S.T. \& Davis, B.J., Mechanism of phthalate ester toxicity in the female reproductive system. Environmental Health Perspectives, 111, pp. 139-146, 2003.

[2] Ribbons, D.W., Keyser, P., Kunz, D.A., Taylor, B.F., Eaton, R.W. \& Anderson, B.N., Microbial degradation of Phthalates. In: Gibson, D. T., 
(ed) Microbial degradation of organic compounds. Marcel Dekker, Inc. New York and Basel. pp. 371-398, 1984.

[3] Caughey, W.S., Smiley, D.J. \& Hellerman, L., L-Glutamic acid dehydrogenase: Structural requirements for substrate competition: effect of Thyroxine. J. Biol. Chem., 224, pp. 591-607,1957.

[4] Smulders, C.J., Bueters, T.J., Van Kleef, R.G. \& Vijverberg, H.P., Selective effects of carbamate pesticides on rat neuronal nicotinic acetylcholine receptors and rat brain acetylcholinesterase. Toxicol. Appl. Pharmacol., 193, pp. 139-146, 2003.

[5] Elespuru R., Lijinsky, W. \& Setlow, J.K., Nitrosocarbaryl as a potent mutagen of environmental significance. Nature, 247, pp. 386-387, 1974.

[6] Wilson, G.D., d'Arcy Doherty, M. \& Cohen, G.M., Selective toxicity of 1naphthol to human colorectal tumor tissue. Br. J. Cancer, 51, pp. 853-63, 1985.

[7] Chapalamadugu, S. \& Chaudhry, G.R.. Hydrolysis of carbaryl by Pseudomonas sp. and construction of a microbial consortium that completely metabolizes carbaryl. Appl. Environ. Microbiol., 57, pp. 744$750,1991$.

[8] Doddamani, H.P. \& Ninnekar, H.Z., Biodegradation of carbaryl by a Micrococcus species. Curr. Microbiol., 43, pp. 69-73, 2001.

[9] Hayatsu, M., Hirano, M. \& Nagata, T., Involvement of two plasmids in the degradation of carbaryl by Arthrobacter sp. strain RC100. Appl. Environ. Microbiol., 65, pp. 1015-1019, 1999.

[10] Larkin, M.J. \& Day, M.J., The metabolism of carbaryl by three bacterial isolates, Pseudomonas sp. (NCIB 12042 \& 12043) and Rhodococcus sp. (NCIB 12038) from garden soil. J. Bacteriol., 60, pp. 233-242, 1986.

[11] Mahajan, M.C., Phale, P.S. \& Vaidyanathan C.S., Evidence for the involvement of multiple pathways in the biodegradation of 1- and 2methylnaphthalene by Pseudomonas putida CSV86. Arch. Microbiol., 161, pp. 425-433, 1994.

[12] Basu, A., Dixit, S.S. \& Phale, P.S., Metabolism of benzyl alcohol via catechol ortho-pathway in methylnaphthalene-degrading Pseudomonas putida CSV86. Appl. Microbiol. Biotechnol., 62, pp. 579-585, 2003.

[13] Phale, P.S., Mahajan, M.C. \& Vaidyanathan, C.S., A pathway for biodegradation of 1-napthoic acid by Pseudomonas maltophilia CSV 89. Arch. Microbiol., 163, pp. 42-47, 1995.

[14] Bellion, E. \& Tan, F., NADP-dependent glutamate dehydrogenase from a facultative methylotroph, Pseudomonas sp. strain AM1. J. Bacteriol., 157, pp. 435-439, 1984.

[15] Patel, T.R. \& Barnsley, E.A., Naphthalene metabolism by Pseudomonads: purification and properties of 1,2-dihydroxynaphthalene oxygenase. $J$. Bacteriol., 143, pp. 668-673, 1980.

[16] Suarez, M., Ferrer, E. \& Martin, M., Purification and biochemical characterization of gentisate 1,2-dioxygenase from Klebsiella pneumoniae M5a1. FEMS Microbiol. Lett., 143, pp. 89-95, 1996. 
[17] Whittaker, J.W., Orville, A.M. \& Lipscomb, J.D., Protocatechuate 3,4dioxygenase from Brevibacterium fuscum. Meth. Enzymol., 188, pp. 8288, 1990.

[18] Kojima, Y., Fujisawa, H., Nakazawa, A., Nakazawa, T., Kanetsuna, F., Taniuchi, H., Nozaki, M. \& Hayashi, O., Studies on pyrocatechase: Purification and spectral properties. J. Biol. Chem., 242, pp. 3270-3278, 1967.

[19] Lowry, O.H., Rosebrough, N.J., Farr, A.L. \& Randall, R.J., Protein measurement with the folin phenol reagent J. Biol. Chem., 193, pp. $265-$ 275, 1951.

[20] Wang, Y.Z., Zhou, Y. \& Zylstra, G.J., Molecular analysis of Isophthalate and Terephthalate degradation by Comamonas testetosteroni. YZW-D Environmental Health Perspectives, 103, pp. 9-12, 1995.

[21] Bollag, J.M., Czaplicki, E.J. \& Minard, R.D., Bacterial metabolism of 1naphthol. J. Agr. Food. Chem., 23, pp. 85-90, 1975.

[22] Walker, N., Janes, N.F., Spokes, J.R. \& Van Berkum, P., Degradation of 1-naphthol by a soil Pseudomonad. J. Appl. Bacteriol., 39, pp. 281-286, 1975.

[23] Rajgopal, B.S., Rao, V.R., Nagendraappa, G. \& Sethunathan, N., Metabolism of carbaryl and carbofuran by soil enrichment and bacterial cultures. Can. J. Microbiol., 30, pp. 1458-1466, 1984. 